\title{
Food insecurity and age at menarche among adolescent girls in Jimma Zone Southwest Ethiopia: a longitudinal study
}

Tefera Belachew ${ }^{1,2^{*}}$, Craig Hadley ${ }^{3}$, David Lindstrom ${ }^{4}$, Yehenew Getachew ${ }^{5}$, Luc Duchateau ${ }^{6}$ and Patrick Kolsteren ${ }^{2,7}$

\begin{abstract}
Background: Age at menarche is the reflection of cumulative pre-adolescent exposure of girls to either adverse environment such as food insecurity or affluent living conditions. Food insecurity could result in inadequate nutrient intake and stress, both of which are hypothesized to have opposing effects on the timing of menarche through divergent pathways. It is not known whether food insecure girls have delayed menarche or early menarche compared with their food secure peers. In this study we test the competing hypothesis of the relationship between food insecurity and age at menarche among adolescent girls in the Southwest Ethiopia.

Methods: We report on 900 girls who were investigated in the first two rounds of the five year longitudinal survey. The semi-parametric frailty model was fitted to determine the effect of adolescent food insecurity on time to menarche after adjusting for socio-demographic and economic variables.

Results: Food insecure girls have menarche one year later than their food secure peer (median age of 15 years vs 14 years). The hazard of menarche showed a significant decline $(P=0.019)$ as severity of food insecurity level increased, the hazard ratio (HR) for mild food insecurity and moderate/severe food insecurity were 0.936 and 0.496 , respectively compared to food secure girls. Stunted girls had menarche nearly one year later than their nonstunted peers $(H R=0.551, P<0.001)$.

Conclusion: Food insecurity is associated with delay of age at menarche by one year among girls in the study area. Stunted girls had menarche one year later than their non-stunted peers. Age at menarche reflects the development of girls including the timing of sexual maturation, nutritional status and trajectory of growth during the pre-pubertal periods. The findings reflect the consequence of chronic food insecurity on the development and well-being of girls in the study area.
\end{abstract}

\section{Background}

Adolescence is a period of rapid transition to adulthood marked by biological changes including sexual maturation. Puberty is a period during adolescence characterized by transformation from a stage of reproductive immaturity to a stage of full reproductive competence. The sign of puberty in girls is menarche (the first menstruation) which occurs at younger age in high income countries [1-5] compared with developing countries in

\footnotetext{
* Correspondence: tefera_belachew@yahoo.com 'Department of Population and Family Health, College of Public Health and Medical Sciences, Jimma University, PO.Box 1104, Jimma, Ethiopia Full list of author information is available at the end of the article
}

Africa [6-10] with minimal decline in those in Latin America [11-13] and Asia [14]. These disparities in age at menarche are related to the improvements in childhood nutrition and health in high income countries among other environmental factors $[13,15,16]$.

There are different theories for the pathways through which environmental factors could influence of age at menarche. An evolutionary theory proposes that adverse childhood experiences [stress, anxiety, insecurity, food insecurity and poor care] accelerate the timing of menarche as an alternative reproductive strategy to maximize the chance of leaving descendents $[17,18]$. Studies have shown that girls who are exposed to

\section{Biomed Central}


adverse life events during the pre-pubertal periods have menarche at a younger age and resume fertility earlier than girls not exposed to such life events $[18,19]$.

Unlike the above theory, the energetics theory suggests energy availability during childhood influences the timing of menarche [20]. It hypothesizes that girls who were exposed to a chronically food and nutrient constrained environment will track their growth more slowly, experience later pubertal development including menarche relative to their genetic potential and reach relatively small adult size compared with those children who were exposed to better food availability.

Adolescents in developing countries are exposed to adverse environmental conditions including food insecurity which could impact on their development and wellbeing. The pathways through which food insecurity can impact on time to menarche may either be through stress, anxiety and insecurity related to concerns around food availability at home [21,22] or through insufficient access to energy and other nutrients for normal health, growth and development [23-32].

It is not known whether food insecurity as an adverse condition would lead to either delayed menarche or early menarche given that it could result in both decreased access to food and increased stress and feeling of insecurity. Evidences from developing countries show that menarche occurs at an older age suggesting indirectly that the effect of food insecurity on age at menarche may be more through nutritional mechanisms $[6,8-10,13]$. Although food insecurity is a common in Ethiopia in general $[33,34]$ and among adolescents in the study area in particular [28], there is no study that documented the relationship between girls' own experience of food insecurity and age at menarche. We previously reported how girls suffered from food insecurity in an Ethiopian context and the health consequences of that food insecurity has on girls $[28,29]$. We now document the effect of food insecurity on age at menarche. In this study, we test the competing hypotheses about the relationship between food insecurity and age at menarche among Ethiopian adolescents.

\section{Methods}

\section{Study sample}

Data for this report is obtained from a longitudinal family survey of youth in the context where a 5 years study is tracking the life events of adolescents as they transit to adulthood in Jimma zone southwest Ethiopia. The survey began in 2005 and involved adolescents and households from a total of 18 "kebeles" (villages) selected from Jimma city and three rural districts, namely Kersa, Dedo and Manna. Manna district is a coffee growing area, Dedo is highland and a vegetable growing area, while Kersa is an edible crop growing plain area with average altitudes of 1911, 2300, 1795 meters above sea level, respectively.

A census was done to generate list of all households which gave a sampling frame for random selection of 3,700 households from the total of 5,795 households in the list. A two-stage sampling plan was used to select the target sample of adolescents. Households were classified into urban (Jimma City), semi-urban (Serbo, Dedo and Yebbu Towns) and six rural communities (two in the vicinity of each of the three small towns). At the first stage, households were randomly sampled with the sample size in each "kebele" determined by the relative proportion of the study population in the "kebele" and the overall target sample size. In the second stage, one adolescent (a boy or a girl) was randomly selected from each household using a Kish Table [35]. Using this sampling strategy a total of 1059 boys and 1025 girls were interviewed in round one. This paper reports on female adolescents interviewed in both the first and the second rounds of the five year longitudinal family survey of youth $(\mathrm{n}=900)$.

\section{Measurements}

Structured household and adolescent level questionnaires were used to collect data. The questionnaires were interviewer-administered and translated in to Amharic and Oromifa languages and checked for consistency by other persons who speak both these languages and English. The household questionnaire included a household registry that collected socio-demographic information on all current resident and nonresident household members including information on their income and food security status. The heads of households responded to the household questionnaire. The adolescent questionnaire focused on issues related to adolescents' experiences of food insecurity, education, health and anthropometric measurements. The interview was conducted in a private place by an interviewer of the same sex as the adolescent respondent after the household interview was completed.

Adolescent food insecurity was measured using a four item index adopted from household food security questionnaires used in developing countries [23-26] by modifying the items that could be used at an individual adolescent level. The details of the methods are described elsewhere $[28,29]$. To summarize briefly, adolescents were asked whether in the last three months they (1) had ever worried about having enough food, (2) had to reduce food intake because of shortages of food or money to buy food, (3) had to go without having eaten because of shortage of food or money to buy food and (4) had to ask outside the home for food because of shortage of food or money to buy food. The index of food insecurity is defined as the number of items with a 
positive answer. The index has high internal consistency (Cronbach's Alpha $=0.81)$.

All data on background characteristics and food insecurity were collected on round one (year 1) of the survey. In round two of the survey, which was conducted one year after the baseline data, female interviewers asked girls whether they had experienced their menarche and the age at which the event had happened using a Non-verbal Responses Card Method [36]. In this method, the interviewers asked questions using a questionnaire and the respondents answered using a laminated A4 size card by inserting a pencil through round holes which are next to the possible responses on the respondent side of the card. The interviewers registered the random numbers next to the responses on the interviewer side of the card. The codes were converted to the actual responses during analysis.

To determine the level of stunting, which is an indicator of chronic malnutrition, trained 12 grade complete data collectors measured height to the nearest $0.1 \mathrm{~cm}$ using a stadiometer (SECA, Hannover Germany). Height for age z-scores were calculated using WHO AnthroPlus software [37] which was coded as stunted(less than -2 ) and non-stunted (-2 and above).

Domestic work index (Workload) was obtained by asking respondents on how many days they were engaged in a variety of tasks including caring for animals, working on farm activities, fetching water and fuel, washing clothes, cooking, engaging in childcare, pounding or grinding grain and engaging in heavy labor tasks during the last seven days before the survey. A principal component analysis was used to develop a workload index based on the range of activities that adolescents were involved in. The first factor was taken based on eigen values and standardized. Higher values correspond to higher workload.

\section{Statistical analysis}

The data were analyzed using STATA 10. The classical way to model the relationship between time-to-event response variable such as time to menarche is based on the Cox Proportional Hazards (PH) model [38]. First, bivariate Cox proportional Hazards Models were fitted to evaluate the marginal effects of different covariates on time to menarche. For the multivariable Cox $\mathrm{PH}$ analyses, different covariates were entered into the model simultaneously and relevant interactions between the covariates were tested. Only variables that showed a significant association with age at menarche in the bivariate analyses were entered in the multivariate model. Since girls are nested (clustered) within villages, this clustering was taken into account by adding a gamma distributed random effect (frailty) to the Cox PH model [39]. Normality of the continuous variables was checked visually using Q-Q plots and household income was divided into tertiles as it is not normally distributed. We present the results as means, proportions and hazard ratios with $95 \%$ confidence intervals.

The study was ethically approved both by the Brown University IRB and by Jimma University Ethical Review Board before the beginning of the data collection.

\section{Results}

After one year follow up a total of 900 girls were interviewed for age at menarche out of 1025 enrolled in the study in round one (125 girls were lost to follow up). Baseline characteristics of girls during the first round survey are presented by food security status in Table 1 . The mean age of girls was $14.8(\mathrm{sd}=1.3$ ) years for food secure and 14.8 $(\mathrm{sd}=1.4)$ years for food insecure girls $(\mathrm{P}$ $>0.05)$. There was no significant difference in food insecurity by place of residence $(\mathrm{P}>0.05)$. Food insecure girls had higher workload compared with food secure peers $(\mathrm{P}<0.001)$ and larger proportion of food insecure girls were part of male headed households $(\mathrm{P}<0.001)$.

At the end of round two out of the 900 girls interviewed, 629 (69.9\%) had experienced menarche. The median age at menarche for the whole sample was 14 years. The median age at menarche differed significantly between the different places of residences, with urban

Table 1 Characteristics of the girls at the first round survey (2005) by Food Security status.

\begin{tabular}{|c|c|c|c|}
\hline Variables & $\begin{array}{c}\text { Food } \\
\text { Secure } \\
(n=675)\end{array}$ & $\begin{array}{c}\text { Food } \\
\text { Insecure } \\
(n=225)\end{array}$ & $P$ \\
\hline Mean age $( \pm S D)$, Years ${ }^{*}$ & $14.8(1.3)$ & $14.8(1.4)$ & 0.956 \\
\hline \multicolumn{4}{|l|}{ Place } \\
\hline Urban & $36.3 \%$ & $40.0 \%$ & 0.218 \\
\hline Semi urban & $28.0 \%$ & $30.7 \%$ & \\
\hline Rural & $35.7 \%$ & $29.3 \%$ & \\
\hline \multicolumn{4}{|l|}{ Sex of the household head } \\
\hline Male & $78.7 \%$ & $91.6 \%$ & $<0.001$ \\
\hline Female & $21.3 \%$ & $8.4 \%$ & \\
\hline \multicolumn{4}{|l|}{ Household income Tertile } \\
\hline Low & $34.8 \%$ & $33.3 \%$ & 0.043 \\
\hline Middle & $30.2 \%$ & $38.7 \%$ & \\
\hline High & $35.0 \%$ & $28.0 \%$ & \\
\hline \multicolumn{4}{|l|}{ Nutritional status } \\
\hline Normal & $77.2 \%$ & $80.8 \%$ & 0.309 \\
\hline Stunted & $22.8 \%$ & $19.2 \%$ & \\
\hline Work index, mean $( \pm S D)^{*}$ & $33.7(17.3)$ & $40.1(17.5)$ & $<0.001$ \\
\hline $\begin{array}{l}\text { Mean highest grade completed }( \pm \\
\text { SD)* }\end{array}$ & $5.3(2.7)$ & $5.2(2.6)$ & 0.014 \\
\hline
\end{tabular}

Source: Jimma Longitudinal Family Survey of Youth; Round 1, 2005-2006. *An independent Samples T-test was used to compare means. Chi-square test was used to compare portions.

Percentages are calculated out of column totals. 
girls having menarche on average one year earlier than semi-urban and rural counter parts, the values being 14 years for the urban (range 13.88 to14.12 years), 15 years (range 14.91 to 15.09 years) for semi-urban areas and 15 years(range 14.99 to15.01 years) for rural areas. Similarly, food insecure adolescents had menarche one year later than those who were food secure, and stunted girls had their menarche one year later than their nonstunted peers.

At the of age of 14 years, for instance, only $23.0 \%$ of the girls with moderate/severe food insecurity had already experienced menarche, compared to $47.0 \%$ and $51.7 \%$ in the mild food insecurity and food secure groups, respectively (Figure 1).

The results of the bivariate Cox regression analyses are presented in Table 2 . Food insecurity $(\mathrm{P}=0.003)$, being a member of female headed household ( $\mathrm{P}=$ $0.049)$ and place of residence $(\mathrm{P}<0.05)$, being stunted $(\mathrm{P}<0.001)$, workload $(\mathrm{P}=0.022)$ and highest household income tertile $(\mathrm{P}=0.016)$ had a significant association with time to menarche in the bivariate analysis. The hazard of having menarche among girls with mild food insecurity and moderate/severe food insecurity were
0.906 (95\% CI: [0.743; 1.103]) and 0.417 (95\% CI: [0.234; $0.745]$ ), respectively compared to food secure ones. The hazard of having menarche among stunted girls was 0.546 (95\% CI: [0.399; 0.747) compared to non-stunted girls $(\mathrm{P}<0.001)$.

Compared to urban girls, the hazard of having menarche among girls in a small towns was 0.817 (95\% CI: $[0.682 ; 0.979])$, while the hazard of menarche among rural girls decreased further to 0.759 (95\% CI: [0.634; 0.910]). Girls in the households with the highest income tertiles had the higher hazard of having menarche compared to those in the low income tertile (HR: 1.264 (95\% CI: [1.045; 1.529]).

The hazard of having menarche among girls in female headed households was 1.213 (95\% CI: [1.001; 1.469]) compared to girls in male headed households. Girls who were members of female headed households had menarche at earlier age compared to those in the male head households.

In the multivariable model, moderate/severe food insecurity had still a significant impact $(\mathrm{P}=0.019)$ on time to menarche after adjusting for place of residence, household income, the sex of the household head and

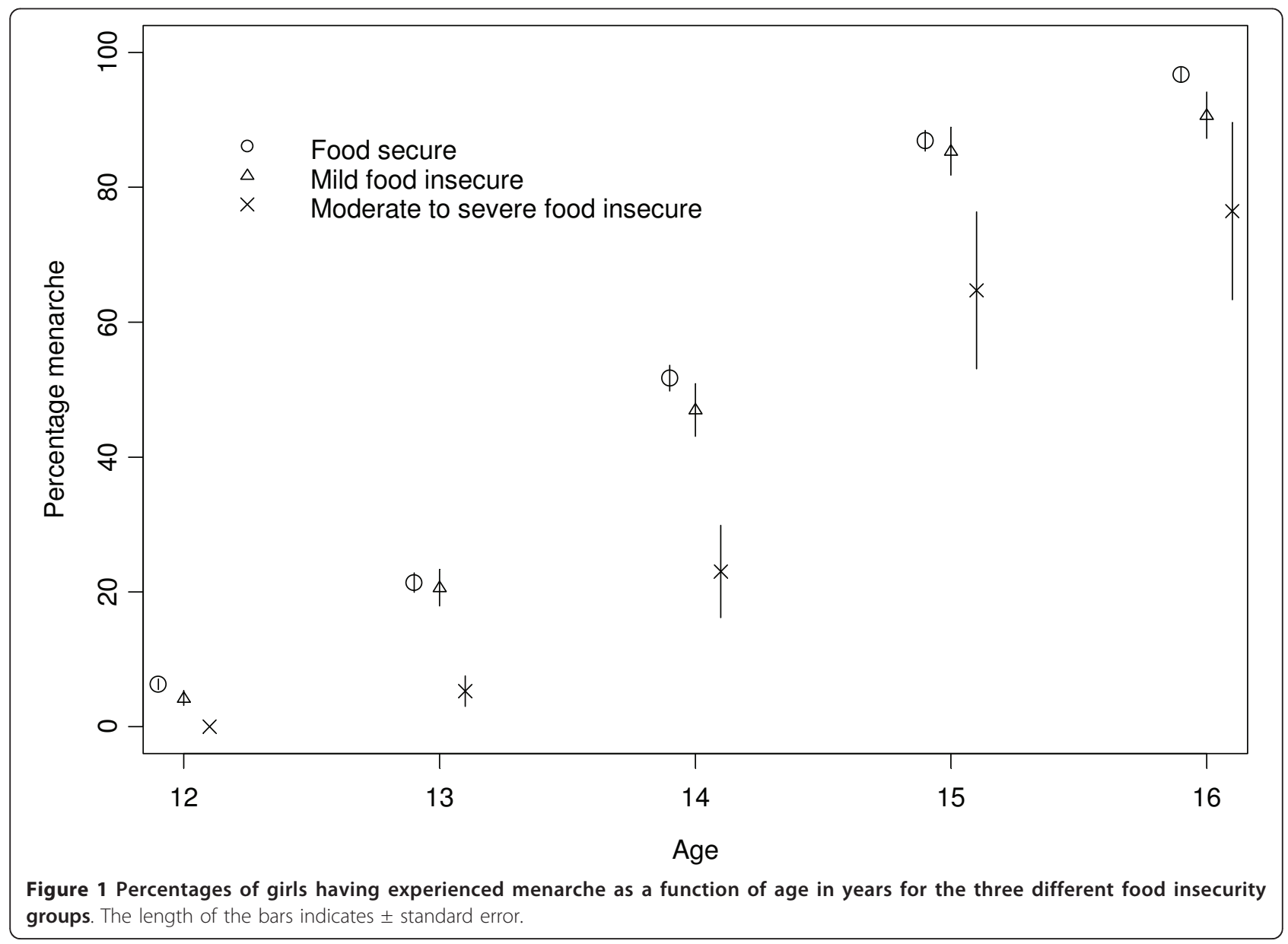


Table 2 Crude (bivariate analysis) from the Cox proportional Hazards Model with time to menarche as response variable.

\begin{tabular}{|c|c|c|}
\hline Covariates & Crude HR $(95 \% \mathrm{Cl})$ & $P$ \\
\hline \multicolumn{3}{|l|}{ Adolescent Food insecurity } \\
\hline Food secure & 1.000 & \\
\hline Mild food insecurity & $0.906(0.743,1.103)$ & 0.326 \\
\hline Moderate/Severe food insecurity & $0.417(0.234,0.745)$ & 0.003 \\
\hline \multicolumn{3}{|l|}{ Place of Residence } \\
\hline Jimma City & 1.000 & \\
\hline Small Towns & $0.817(0.682,0.979)$ & 0.028 \\
\hline Rural & $0.759(0.634,0.910)$ & 0.003 \\
\hline \multicolumn{3}{|l|}{ Nutritional status(Height for age z-score) } \\
\hline Normal & 1.00 & \\
\hline Stunted & $0.546(0.399,0.747)$ & $<0.001$ \\
\hline Work Index & $0.994(0.990,0.999)$ & 0.022 \\
\hline \multicolumn{3}{|l|}{ Household income Tertiles } \\
\hline Low & 1. 000 & \\
\hline Middle & $1.011(0.834,1.126)$ & 0.911 \\
\hline High & $1.264(1.045,1.529)$ & 0.016 \\
\hline \multicolumn{3}{|l|}{ Head of the household } \\
\hline Male & 1.000 & \\
\hline Female & $1.213(1.001,1.469)$ & 0.049 \\
\hline
\end{tabular}

Source: Jimma Longitudinal Family Survey of Youth; Round 1, 2005-2006; Round 2, 2006-2007.

Data on predictors were collected one year before the dependent variable (age at menarche).

$\mathrm{HR}=$ Hazard Ratio

$\mathrm{Cl}=$ Confidence Interval.

place of residence. The hazard of menarche showed a significant decline to 0.936 (95\% CI: $[0.756 ; 1.158])$ and 0.496 (95\% CI: [0.276; 0.892]), respectively for mild food insecurity and for moderate/severe food insecurity compared to food secure girls. Similarly, stunted girls had lower hazard of having menarche compared with their non-stunted peers $(\mathrm{HR}=0.551, \mathrm{P}<0.001)$. Place of residence, household income, work index and sex of the household head did no longer have a significant impact on time to menarche on the multivariable analyses (Table 3).

\section{Discussion}

Food insecurity is prevalent among adolescents in the study area $[28,29]$. Our results showed that food insecurity is associated with delayed age at menarche and food insecure girls had their menarche on average one year later than their food secure peers. These findings can be well explained by the energetics theory where delay in age at menarche among food insecure adolescents may be associated with inadequate nutrient intake [20]. In the situation of food insecurity individuals use food related coping strategies that would lead to decreases in the quantity and quality of food consumed
Table 3 Adjusted hazard ratios (multivariate analysis) from the Cox Proportional Hazards model with time to menarche as response variable.

\begin{tabular}{|c|c|c|}
\hline Covariates & $\begin{array}{l}\text { Adjusted HR (95\% } \\
\mathrm{Cl})\end{array}$ & $P$ \\
\hline \multicolumn{3}{|l|}{ Adolescent Food insecurity } \\
\hline Food secure & 1.000 & \\
\hline Mild food insecurity & $0.936(0.756,1.158)$ & 0.542 \\
\hline Moderate/Severe food insecurity & $0.496(0.276,0.892)$ & 0.019 \\
\hline \multicolumn{3}{|l|}{ Place of Residence } \\
\hline Jimma City & 1.000 & \\
\hline Small Towns & $0.859(0.705,1.045)$ & 0.128 \\
\hline Rural & $0.885(0.951 ; 1.126$ & \\
\hline \multicolumn{3}{|l|}{$\begin{array}{l}\text { Nutritional status(Height for age z- } \\
\text { score) }\end{array}$} \\
\hline Normal & 1.000 & \\
\hline Stunted & $0.551(0.402 ; 0.755)$ & $<0.001$ \\
\hline Work Index & $0.997(0.992 ; 1.003)$ & 0.383 \\
\hline \multicolumn{3}{|l|}{ Household income Tertiles } \\
\hline Low & 1.000 & \\
\hline Middle & $1.004(0.818,1.233)$ & 0.968 \\
\hline High & $1.195(0.967,1.476)$ & 0.098 \\
\hline \multicolumn{3}{|l|}{ Head of the household } \\
\hline Male & 1.000 & \\
\hline Female & $1.135(0.927,1.389)$ & 0.220 \\
\hline
\end{tabular}

Source: Jimma Longitudinal Family Survey of Youth; Round 1, 2005-2006; Round 2, 2006-2007.

Data on predictors were collected one year before the dependent variable (age at menarche).

$\mathrm{HR}=$ Hazard Ratio.

$\mathrm{Cl}=$ confidence interval.

$[25,40,41]$. Analysis of data from the same cohort of adolescent showed that food insecure girls have low quality diets [Unpublished]. Decreased food intake affects the maturation of the hormonal system that controls the occurrence of menarche. After birth, the hypothalamo-pituitary-gonadal axis continues to mature until menarche and the first years of menstruation. This process is characterized by changes in amplitude and pulsatility of Hypothalamic Gonadotrophine Releasing Hormon [42]. This development requires adequate supply of energy and other nutrients which are unlikely to be met in food insecure situation. The longstanding negative effects of childhood food insecurity on reproductive function of adult women has been also evidenced following the Dutch famine [43].

The results also showed that stunted girls had delayed age at menarche similar to the reports of studies in Senegal and Kenya which indicated that post-menarcheal girls had better nutritional status than pre-menarcheal ones $[44,45]$. Improved nutrition during early childhood has been reported to result in earlier fertility $[5,16,46]$. 
The mean age at menarche observed among girls in the study area (14 years) is higher than the age at menarche in developed countries $[1,5,47]$ and even later than age at menarche for girls in developing countries in Africa [7-10], Asia [14,48] and Latin America [11,12].

Although menarche is mainly (50-70\%) determined by genetic factors [49-51], environmental factors such as food insecurity have also a role in predicting age at menarche. Delayed age at menarche is associated with decreased fertility [52] poor reproductive function and other health problems including osteoporosis at later life [53], while early menarche is associated with breast cancer [54]. In the study area's context, the observed overall delay in age to menarche is indicative of the pre-pubertal suboptimal nutrition of girls in the study area who may have been suffering from the consequences of chronic food insecurity; which gives public health significance to the finding. These results highlight clues to the fact that the cumulative nutritional histories of girls in the study area may not be optimal during the prepubertal childhood periods. This will have intergenerational effects as childhood malnutrition leads to malnutrition during adulthood [55].

It was also observed that compared to girls in the urban areas, those in the rural and semi-urban areas had menarche one year later, which is consistent with the reports of other studies in developing countries [7-10] and in northern part of Ethiopia [56]. The difference could be due to the fact that larger proportion of girls in the urban areas were from households in the higher income tertile and rural girls have higher workload compared to those in the urban and semi urban areas. Both these factors increase the probability that urban girls have earlier menarche. However, the differences in age at menarche between urban and rural girls did not persist in the multivariable model.

Other reports indicated that vigorous physical activity is associated with decreased estrogen secretion and increased age at menarche due to the disturbance of GnRH pulsatility $[57,58]$. Although our data showed a significant association between work index and delayed age at menarche in the bivariate model, the association disappeared when adjusting for other covariates suggesting that the effect of workload may be mediated by other variables in the model.

It is possible that the effects of food insecurity could be mediated through stunting. However, our analysis showed that there is no correlation between food insecurity and stunting $(P=0.309)$ and the change in the effect of food insecurity when entering stunting into the model was not significant indicating that there is no mediation.

We used menarche as it is the most easily assessed and reliable self-reported aspect of female sexual maturity
[59]. To reduce social desirability bias due to the private nature of the subject, we used a Non-verbal Response Card Method in interviewing girls about the occurrence of menarche and their age at the event [36]. The non-verbal Response Card Method is a local improvisation of the Computer Assisted Self Interview [CASI] method which is validated for use in developed countries [60,61].

In conclusion, food insecurity is associated with delay of age at menarche among girls in the study area. Stunted girls had menarche on average one year later than their non-stunted peers. Age at menarche reflects the development of girls including the timing of sexual maturation, nutritional status, and trajectory of growth during the pre-pubertal periods and wellbeing of girls. The fact that girls in the study area had menarche later than girls in developed countries and other low income countries reflects the consequence of chronic food insecurity on the development and well-being of girls in the southwest Ethiopia.

\section{Acknowledgements}

The Jimma Longitudinal Family Survey of Youth was funded by the Packard Foundation, Campton Foundation, National Institute of Health and National Science Foundation. We also Acknowledge Prof. Abebe Gebremariam, Prof. Challi Jira, Mr. Fasil Tessema, Dr. Kifle Woldemichael, the study participants, data collectors and data encoders.

\section{Author details}

${ }^{1}$ Department of Population and Family Health, College of Public Health and Medical Sciences, Jimma University, PO.Box 1104, Jimma, Ethiopia.

${ }^{2}$ Department of Food Safety and Food Quality, Faculty of Bioscience Engineering, Ghent University, Coupure Links 653, B-9000 Gent, Belgium.

${ }^{3}$ Department of Anthropology, Emory University, 207 Anthropology Building 1557 Dickey Drive, USA. ${ }^{4}$ Department of Sociology, Brown University, Box 1916, Providence, RI 02912, USA. ${ }^{5}$ Yehenew Getachew, Collage of Agriculture and Veterinary Medicine, Jimma University, Jimma, Ethiopia. ${ }^{6}$ Department of Physiology \& Biometrics, Faculty of Veterinary Medicine, Ghent University, Belgium. ${ }^{7}$ Nutrition and Child Health Unit, Department of Public Health, Institute of Tropical Medicine, Nationalestraat 155, 2000 Antwerpen, Belgium.

\section{Authors' contributions}

The authors' responsibilities were as follows- DL, CH, TB: designed and supervised the study and ensured quality of the data and made a substantial contribution to the local implementation of the study and PK, $L D, Y G, D L, T B, C H$, and contributed in the analysis and interpretation of the data. $\mathrm{TB}$, the corresponding author wrote the manuscript and had the final responsibility to submit it for publication. All authors read and approved the final manuscript

\section{Competing interests}

The authors declare that they have no competing interests.

Received: 22 June 2011 Accepted: 13 September 2011

Published: 13 September 2011

\section{References}

1. Fredriks M, vanBuuren S, Oostdijk W, Verllove-Vanhorick SP, Wit JM: Pubertal development in the Netherlands, 1965-1997. Pediatr Res 2001, 50:479-486.

2. Papadimitriou $A$ : Sex differences in the secular changes in pubertal maturation. Pediatrics 2001, 108:65.

3. Bellis MA, Downing J, Ashton JR: Adults at 12? Trends in puberty and their public health consequences. Epidemiol Community Health 2006, 60:910-911. 
4. Anderson SE, Dallal GE, Must A: Relative weight and race influence average age at menarche: results from two nationally representative surveys of us girls studied 25 years apart. Pediatrics 2003, 111(4):844-850.

5. Rosenfield RL, Lipton RB, Drum ML: Thelarche, Pubarche, and Menarche Attainment in Children with Normal and Elevated Body Mass Index. Pediatrics 2009, 123:84-88.

6. Prentice S, Fulford AJ, Jarjou LM, Goldberg GR, Prentice A: Evidence for a downward secular trend in age of menarche in a rural Gambian population. Ann Hum Biol 2010, 37(5):717-721.

7. Padez C: Age at menarche of schoolgirls in Maputo, Mozambique. Ann Hum Biol 2003, 30(4):487-495.

8. Oduntan SO, Ayeni O, Kale OO: The age of menarche in Nigerian girls. Ann Hum Biol 1976, 3(3):269-274.

9. Pasquet P, Biyong AM, Rikong-Adie H, Befidi-Mengue R, Garba MT, Froment $A$ : Age at menarche and urbanization in Cameroon: current status and secular trends. Ann Hum Biol 1999, 26(1):89-97.

10. Attallah NL: Age at menarche of schoolgirls in Khartoum. Ann Hum Biol 1983, 10(2):185-188.

11. Ossa XM, Munoz S, Amigo H, Bangdiwala Sl: Secular trend in age at menarche in indigenous and non-indigenous women in Chile. Am J Hum Biol 2010, 22:688-694.

12. Silva HP, Padez C: Secular Trends in Age at Menarche Among Caboclo Populations From Para, Amazonia, Brazil: 1930-1980. Am J Hum Biol 2006, 18:83-92.

13. Padez C, Rocha MA: Age at menarche in Coimbra (Portugal) school girls: a note on the secular changes. Ann Hum Biol 2003, 30(5):622-632.

14. Bagga A, Kulkarni S: Age at menarche and secular trend in Maharashtrian (Indian) girls. Acta Biol Szeged 2000, 44(1-4):53-57.

15. Gluckman PD, Hanson MA: Evolution, development and timing of puberty. Trends Endocrinol Metab 2006, 17:7-12.

16. Ramakrishnan U, Barnhart H, Schroeder DG, Stein AD, Martorell R: Early childhood nutrition, education and fertility milestones in Guatemala. J Nutr 1999, 129:2196-2202.

17. Belsky J, Steinberg L, Draper P: Childhood experience, interpersonal development, and reproductive strategy: An evolutionary theory of socialization. Child Dev 1991, 62:647-670.

18. Chisholm JS, Quinlivan JA, Petersen RW, Coal DA: Early stress predicts age at menarche and first birth, adult attachment and expected life span. Hum Nat 2005, 16(3):233-265

19. Jorm AF, Christensen $H$, Rodgers B, Jacomb PA, Easteal S: Association of adverse childhood experiences, age of menarche, and adult reproductive behavior: does the androgen receptor gene play a role? Am J Med Genet B Neuropsychiatr Genet 2004, 125B(1):105-111.

20. Peter T: Energetics, reproductive ecology and human evolution. PaleoAnthropology 2008, 172-200.

21. Belsky DW, Moffitt TE, Arseneault L, Melchior M, Caspi A: Context and sequelae of food insecurity in children's development. Am J Epidemiol 2010, 172:809-818.

22. Cook JT, Frank DA: Food security, poverty, and human development in the United States. Ann N Y Acad Sci 2008, 1136:193-209.

23. Coates J, Frongillo EA, Rogers BL, Webb P, Wilde PE, House R: Commonalities in the experience of household food insecurity across cultures: what are measures missing? J Nutr 2006, 136:1438S-1448S.

24. Frongillo EA, Nanama S: Development and validation of an experiencebased measure of household food security within and across seasons in northern Burkina Faso. J Nutr 2006, 136(5):1409S-1419S.

25. Melgar-Quinonez HR, Zubieta AC, MkNelly B, Nteziyar-emye A, Gerardo MF, Dunford C: Household food insecurity and food expenditure in Biolivia, Burkina Faso and the Philippines. J Nutr 2006, 136(5):1431S-1437S.

26. Webb P, Coates J, Frongillo EA, Rogers BL, Swindale A, Bilinsky P: Measuring household food insecurity: why it's so important and yet so difficult to do? J Nutr 2006, 136:1404S-1408S.

27. Hadley C, Patil CL: Food insecurity in rural Tanzania is associated with maternal anxiety and depression. Am J Hum Biol 2006, 18(3):359-368

28. Hadley C, Lindstrom D, Tessema F, Belachew T: Gender bias in food insecurity experiences of adolescents in Jimma Zone. Social Sc Med 2008, 66:427-438

29. Belachew T, Hadley C, Lindstrom D, Getachew Y, Gebremariam A, Woldemichael K, Lachat C, Kolstren P: Gender differences in food insecurity and morbidity among adolescents in southwest Ethiopia. Pediatrics 2011, e397-404.
30. Chilton M, Black MM, Berkowitz C, Casey PH, Cook J, Cutts D, Jacobs RR, Heeren T, de Cuba SE, Coleman S, Meyers A, Frank DA: Food insecurity and risk of poor health among US-born children of immigrants. Am J Public Health 2009, 99(3):556-562.

31. Casey PH, Szeto KL, Robbins JM, Stuff JE, Connell C, Gossett JM, Simpson PM: Child health-related quality of life and household food security. Arch Pediatr Adolesc Med 2005, 159(1):51-56.

32. Winicki J, Jemison K: Food insecurity and hunger in the Kindergarten: its effect on learning and growth. Contemp Econ Policy 2003, 21(2):145-157.

33. Devereux S, Sussex I: Food Insecurity in Ethiopia, a discussion paper for DFID. 2000.

34. Webb P, Von Braun J: Famine and Food Security in Ethiopia: Lessons for Africa. Chichester: John Wiley and Sons; 1994.

35. Kish L: A procedure for objective respondent selection within the household. J Am Stat Assoc 1949, 44:380-387.

36. Lindstrom DP, Hattori MK, Hogan D, Tessema F: Nonmarital sex and condom knowledge among Ethiopian young people: improved estimates using a nonverbal response card. Stud Fam Plann 2010, 41(4):251-262.

37. WHO: AnthroPlus for personal computers Manual: Software for assessing growth of the world's children and adolescents. Geneva: WHO; 2009 [http://www.who.int/growthref/tools/en/].

38. Cox DR: Regression models and life tables. J R Stat Soc Series B Stat Methodol 1972, 34(2):187-220

39. Duchateau L, Janssen P: The frailty model. Springer Verlag; 2008.

40. Norhasmah S, Zalilah MS, Mohd Nasir MT, Kandiah M, Asnarulkhadi AS: A qualitative study on coping strategies among women from food insecurity households in Selangor and Negeri Sembilan. Mal J Nutr 2010, 16(1):39-54.

41. Maxwell D, Watkins B, Wheeler R, Collins G: The coping strategies index: A tool for rapidly measuring food security and the impact of food aid programmes in emergencies. FAO; 2003 [http://www.fao.org/ crisisandhunger/root/pdf/maxwell.pdf], Accessed on March 16, 2011

42. Apter D, Hermanson E: Update on female pubertal development. Curr Opin Obstet Gynecol 2002, 14:475-481.

43. Elias SG, van Noord PAH, Peeters PHM, den Tonkelaar I, Grobbee DE: Childhood exposure to the 1944-1945 Dutch famine and subsequent female reproductive function. Hum Reprod 2005, 20(9):2483-2488.

44. Simondon KB, Simon I, Simondon F: Nutritional status and age at menarche of Senegalese adolescents. Ann Hum Biol 1997, 24(6):521-532.

45. Leenstra T, Petersen LT, Kariuki SK, Oloo1 AJ, Kager PA, Ter Kuile FO: Prevalence and severity of malnutrition and age at menarche; crosssectional studies in adolescent schoolgirls in western Kenya. Eur J Clin Nutr 2005, 59:41-48.

46. Cole TJ: Secular trends in growth. Proceedings of the Nutrition Society 2000, 59:317-324.

47. Theodoropoulou A, Markou KB, Vagenakis GA, Benardot D, Leglise M, Kourounis G, Vagenakis AG, Georgopoulos NA: Delayed but normally progressed puberty is more pronounced in artistic compared with rhythmic elite gymnasts due to the intensity of training. J Clin Endocrinol Metab 2005, 90(11):6022-6027.

48. Banik SD: Evaluation of health status of pre-menarcheal and postmenarcheal girls by Rohrer index in Purulia, West Bengal. Journal of Public Health and Epidemiology 2011, 3(1):13-16.

49. van den Berg SM, Boomsma DI: The familial clustering of age at menarche in extended twin families. Behav Genet 2007, 37:661-667.

50. Anderson CA, Duffy DL, Martin NG, Visscher PM: Estimation of variance components for age at menarche in twin families. Behav Genet 2007, 37:668-677.

51. Liu YZ, Guo YF, Wang L, Tan LJ, Liu XG, Pei YF, Yan H, Xiong DH, Deng FY, Yu N, Zhang YP, Zhang L, Lei SF, Chen XD, Liu HB, Zhu XZ, Levy S, Papasian CJ, Drees BM, Hamilton JJ, Recker RR, Deng HW: Genome-wide association analyses identify SPOCK as a key novel gene underlying age at menarche. PLoS Genet 2009, 5(3):e1000420.

52. Komura H, Miyake A, Chen CF, Tanizawa O, Yoshikawa H: Relationship of age at menarche and subsequent fertility. Eur J Obstet Gynecol Reprod Biol 1992, 44(3):201-203.

53. Ito M, Yamada M, Hayashi K, Ohki M, Uetani M, Nakamura T: Relation of early menarche to high bone mineral density. Calcif Tissue Int 1995, 57(1):11-14. 
54. Apter D, Vihko R: Early menarche, a risk factor for breast cancer, indicates early onset of ovulatory cycles. J Clin Endocrinol Metab 1983, 57(1):82-86.

55. Alderman $\mathrm{H}$, Hoddinotty J, Kinsey B: Long term consequences of early childhood malnutrition. Oxford Economic Papers 2006, 58:450-474.

56. Zegeye DT, Megabiaw B, Mulu A: Age at menarche and the menstrual pattern of secondary school. BMC Women's Health 2009, 9:29.

57. Ziomkiewicz A, Ellison PT, Lipson SF, Thune I, Jasienska G: Body fat, energy balance and estradiol levels: a study based on hormonal profiles from complete menstrual cycles. Hum Reprod 2008, 23(11):2555-2563.

58. Warren MP, Perlroth NE: The effects of intense exercise on the female reproductive system. J Endocrinol 2001, 170:3-11.

59. Brooks-Gunn J, Warren MP, Rosso J, Gargiulo J: Validity of self-report measures of girls' pubertal status. Child Dev 1997, 58(3):829-841.

60. Cooleya PC, Rogersb SM, Turnerb CF, Al-Tayyibb AA, Willisb G, Ganapathi L: Using touch screen audio-CASI to obtain data on sensitive topics. Comput Human Behav 2001, 17:285-293.

61. Newman CJ, Des Jarlais DC, Turner CF, Gribble J, Cooley P, Paone P: The differential effects of face-to-face and computer interview modes. Am Public Health 2002, 92(2):294-297.

doi:10.1186/1477-7827-9-125

Cite this article as: Belachew et al:: Food insecurity and age at menarche among adolescent girls in Jimma Zone Southwest Ethiopia: a longitudinal study. Reproductive Biology and Endocrinology 2011 9:125.

\section{Submit your next manuscript to BioMed Central} and take full advantage of:

- Convenient online submission

- Thorough peer review

- No space constraints or color figure charges

- Immediate publication on acceptance

- Inclusion in PubMed, CAS, Scopus and Google Scholar

- Research which is freely available for redistribution

Submit your manuscript at www.biomedcentral.com/submit 